\title{
Possible Benefits of the Coriandrum sativum in the Management of Diabetes in Animal Model: A Systematic Review
}

\begin{abstract}
Diabetes mellitus (DM) is a group of a metabolic disease characterized by chronic hyperglycemia and disturbances of carbohydrate, lipid, and protein metabolism, resulting from defects in insulin secretion, or action or both. DM caused at least $12 \%$ of global health expenditure is spent on diabetes (\$ USD 673 billion). The control of diabetes with fewer side effects is a challenge. Authors have reported that herbal medicine would be an alternative to manage DM. Coriandrum sativum (Coriander) is a plant that has been used in the management of the diabetes. The purpose of this study was to review the published research concerning the use of coriander in the treatment of DM in animal models using a database. The papers were searched in the PubMed. It was verified a strong interest in studies involving diabetes. It is also observed that about $6.92 \%$ of the articles with the keyword "Coriandrum sativum" are related to diabetes. Five studies have reached the inclusion criteria to be analyzed. In all these investigations a reduction of the plasma level of glucose was detected in the animals treated with coriander. In conclusion, putting together the findings described in this study and considering the results in the publications, it is possible to conclude and to suggest that the use of coriander could be suitable to try to decrease plasma glucose level of diabetic animals. However, it is important to consider the limited number of publications available in the PubMed involving searches evaluating the antidiabetic effect of coriander.
\end{abstract}

Keywords: Coriandrum sativum; Diabetes; PubMed; Experimental model; Glucose

Received: January 27, 2016; Accepted: February 15, 2016; Published: February 20, 2016

\section{Introduction}

Diabetes mellitus (DM) is a group of a metabolic disease characterized by chronic hyperglycemia and disturbances of carbohydrate, lipid, and protein metabolism, resulting from defects in insulin secretion, or action or both $[1,2]$. There are mainly three forms of diabetes: Type 1 DM, Type 2 DM, and gestational diabetes [3]. Briefly, Type 1 DM results from the body's failure to produce insulin; Type 2 DM is due to insulin resistance, and gestational diabetes develops during pregnancy [4]. The International Diabetes Federation (IDF) predicts that 415 million people world-wide have diabetes and by 2040 this will rise to 642 million. It is also predict that $77 \%$ of people with diabetes live in low- and middle-income countries. DM caused at least $12 \%$ of global health expenditure is spent on diabetes (\$ USD 673 billion) [5]. The control of diabetes with fewer side effects is a challenge
Frederico EHFF ${ }^{1}$, Cardoso ALBD ${ }^{2}$, Guimarães $\mathrm{CAS}^{2}$, Neves $\mathrm{RF}^{2}$, Sá-Caputo $\mathrm{DC}^{3}$, Moreira-Marconi $E^{3}$, Dionello $\mathrm{CF}^{4}$, Morel DS ${ }^{4}$, Paineiras-Domingos $\mathrm{LL}^{4}$, Costa-Cavalcanti $\mathbf{R G}^{5}$, Sousa-Gonçalves $\mathrm{CR}^{2}$, Pereira $\mathrm{FG}^{2}$, Souza $\mathrm{PL}^{2}$ Arnóbio $A^{4}$ and

\section{Bernardo-Filho $\mathrm{M}^{2}$}

1 Programa de Pós-graduação em Biociências, Instituto de Biologia Roberto Alcantara Gomes, Universidade do Estado do Rio de Janeiro, Rio de Janeiro, 20551-030, RJ, Brasil

2 Laboratório de Vibrações Mecânicas e Práticas Integrativas e Complementares, Departamento de Biofísica e Biometria, Instituto de Biologia Roberto Alcantara Gomes, Universidade do Estado do Rio de Janeiro, Rio de Janeiro, 20551-030, RJ, Brasil

3 Programa de Pós-Graduação em Fisiopatologia Clínica e Experimental, Faculdade de Ciências Médicas, Universidade do Estado do Rio de Janeiro, Rio de Janeiro, 20551-030, RJ, Brasil

4 Programa de Pós-Graduação em Ciências Médicas, Faculdade de Ciências Médicas, Universidade do Estado do Rio de Janeiro, Rio de Janeiro, 20551-030, RJ, Brasil

5 Mestrado Profissional em Saúde, Medicina Laboratorial e Tecnologia Forense, Universidade do Estado do Rio de Janeiro, Instituto de Biologia Roberto Alcantara Gomes, Av. Marechal Rondon, Rio de Janeiro, 20950-003, RJ, Brasil

Corresponding author: Frederico Éric HFF

” ericfrederico@msn.com

Programa de Pós-graduação em Biociências, Instituto de Biologia Roberto Alcantara Gomes, Universidade do Estado do Rio de Janeiro, Rio de Janeiro, 20551-030, RJ, Brasil. 
Tel: 55-21-28688332

Citation: Frederico EHFF, Cardoso ALBD, Guimarães CAS, et al. Possible Benefits of the Coriandrum sativum in the Management of Diabetes in Animal Model: A Systematic Review Herb Med. 2016, 2:1.

[6]. Due the increasing prevalence of the disease, the significant morbidity associated with diabetic complications [7] and the side effects associated with the use of insulin and oral hypoglycemic agents, there is an increasing demand by patients to use natural products with antidiabetic activity [8], through their free radicalscavenging activity [9].

Increased free radical generation and oxidative stress play an important role in the pathogenesis of DM and its late complications. In DM the efficiency of the antioxidant properties is altered. Antioxidants act against the free radicals and protect the human body from various diseases [10]. Ramadan et al. [11] have reported that DM is associated with overproduction of free radicals and diminution of antioxidants. Free radicals mediate activation of signal transduction cascades and transcriptional factors leading to expression of specific genes that produces tissue damage and ultimately to diabetes complication [12]. Several studies have revealed that a strong part of the antioxidant activity may be found in chemical compounds such as flavonoids, flavones, isoflavones, anthocyanin, catechin, and other phenolic compounds $[13,14]$.

Authors have reported that herbal medicines are good source of antioxidants $[15,16]$. In addition, medicinal plants have been used in various countries in the treatment of various diseases $[17,18]$, as the diabetes [19-21]. One of these is Coriandrum sativum (Coriander) [19].

Coriandrum sativum (Coriander) is a plant that has been used in the management of the diabetes $[22,23]$. It is an herbaceous plant originally from the Mediterranean and Middle Eastern regions, belonging to family Apiaceae [24]. Furthermore, it is successfully grown in a wide range of conditions [25]. It is cultivated for its aromatic leaves and seeds in North Africa, Central Europe and Asia as a spice and medicine [26]. There is a large number of compounds isolated from coriander, including flavonoids (quercetin and isoquercetin), polyphenols (rutin, caffeic acid derivatives, ferrulic acid, gallic acid and chlorogenic acid), $\beta$-caroteinoids, anethole, borneol, camphene, camphor, carvone, cineole, citronelol, coriandrol, coriandrin, coumarins and hydroxy-coumarins (umbelliferone and scopoletin). Furthermore, the $p$-cymene, euginol, geraniol, geranyl acetate, limonene, $d$ $(+)$-linalool, myrcene, $\alpha$ - and $\beta$-phellandrene, $\alpha$ - and $\beta$-pinenes, $\alpha$ - and $\gamma$-terpinene, 5- and 8-methoxypsoralens, tannins, and many others [27-29].

Coriander is known to possess antifungal, antibacterial [30], free radical scavenging, and lipid per oxidation activities [31]. In traditional medicine, it is used for the treatment of diabetes, gastrointestinal complications such as dyspepsia, flatulence, diarrhea, vomiting [32] and as an antiseptic and emmenagogue [33].

Some authors have demonstrated the antidiabetic effect of coriander $[12,19,22,23]$. Therefore, the purpose of this study was to review the published research concerning the use of coriander in the treatment of DM in animal models using a database. Considering the findings described in the literature, it is hypothesized a decrease of the glucose in the diabetic animals treated with coriander.

\section{Methods}

\section{Search strategy and selection of the studies}

This systematic review of scientific studies followed the guidelines of the Transparent Reporting of Systematic Reviews and Meta-Analyses (PRISMA statement) [34]. One database was systematically searched for experimental trials in vivo and in vitro. The papers were searched in the PubMed, (http://www.ncbi.nlm. nih.gov/pubmed) on January $15^{\text {th }}, 2016$. The search was performed using the keyword "Coriandrum sativum" and diabetes.

\section{Inclusion and exclusion criteria}

A systematic selection of the articles was carried out by three independent examiners based on the following inclusion criteria: (i) Biological activity: antihyperglycemic or antidiabetic activity of Coriandrum sativum; (ii) Plant material: extract from Coriandrum sativum; (iii) Study design: experimental trials in vitro and/or in vivo (with coriander and diabetic animals); (iv) Language: articles written in English. In addition, ethnobotanical and ethnopharmacological surveys, case reports, expert opinion or consensus statements were excluded, as those have used Coriandrum sativum mixed with other product.

Table 1 Number of publications (database PubMed) involving "Coriandrum sativum" and diabetes.

\begin{tabular}{|l|c|}
\hline Keyword & Number of publication \\
\hline Coriandrum & 302 \\
\hline "Coriandrum sativum" & 231 \\
\hline Coriander & 475 \\
\hline "Coriandrum sativum" AND diabetes & 16 \\
\hline "Coriandrum sativum" AND "diabetes & 9 \\
\hline mellitus" & 17 \\
\hline Coriander AND diabetes & 9 \\
\hline Coriander AND "diabetes mellitus" & 533489 \\
\hline Diabetes & 387100 \\
\hline "Diabetes mellitus"
\end{tabular}




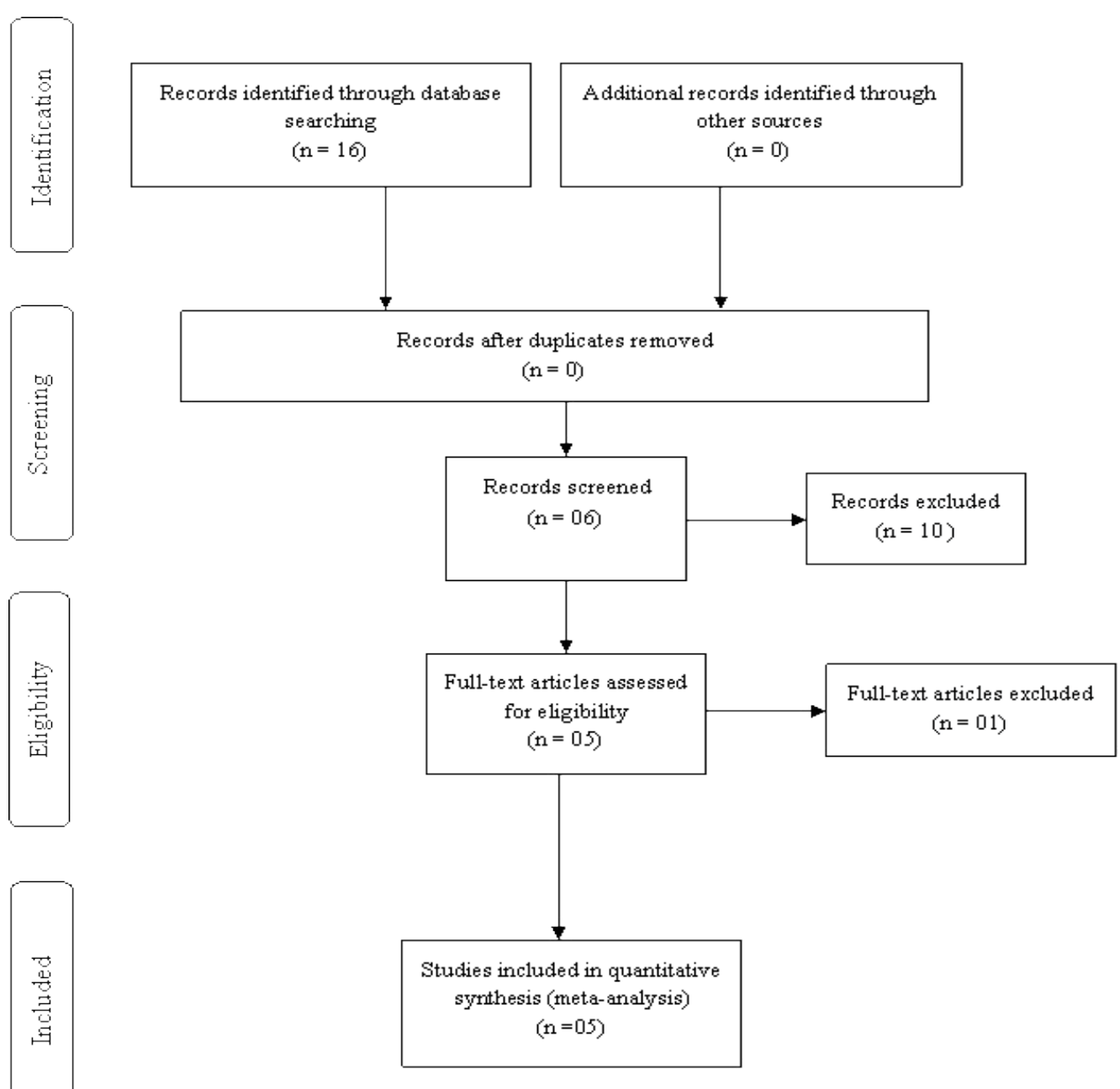

Figure 1 Flow diagram of the search strategy comprising the identification of potentially relevant material, and preliminary screening and final selection of the studies included in this review (based on PRISMA statements).

Table 2 Information about the animals and plant material used on the selected studies.

\begin{tabular}{|c|c|c|c|c|c|c|}
\hline & & Animal & & & Coriandrum sativum (CS) & \\
\hline Animal used & Number & Weight & Age & Source & Preparation of the extract & Reference \\
\hline Rat & 30 & $150-180 \mathrm{~g}$ & $N / I$ & in natura & $\begin{array}{l}\text { Coriander leaves and stem ( } 450 \mathrm{~g}) \text { were finely chopped before } \\
\text { extraction with aqueous ethanol }(80 \%) \text { for } 24 \mathrm{~h} \text {. After the removal } \\
\text { of the solvent in vacuo, the crude extract ( } 18 \mathrm{~g} \text { ) was suspended in } \\
\text { distilled water and extracted with } 150 \mathrm{~mL} \text { portions of ethyl acetate } \\
\text { until the extracts were nearly colorless. Solvents were removed in } \\
\text { vacuo, and the yield of } 6.5 \mathrm{~g} \text { and } 4.4 \mathrm{~g} \text {, respectively, were obtained. }\end{array}$ & [22] \\
\hline Rat & 24 & $180-200 \mathrm{~g}$ & 7-8 weeks & commercial & $\begin{array}{l}\text { The seeds were ground into a fine powder. Powder material }(1 \mathrm{~g}) \text { was } \\
\text { boiled for } 30 \mathrm{~min} \text { in } 40 \mathrm{ml} \text { cold distilled water-cooled. This suspension was } \\
\text { filtered and the volume was made up to } 40 \mathrm{ml} \text { with distilled water }\end{array}$ & [12] \\
\hline
\end{tabular}

N/I - Non informed, CS - Coriandrum sativum 


\section{Results}

Table 1 shows the number of publications searched in the PubMed involving the keywords coriander and diabetes. It is possible to verify a strong interest in studies involving diabetes. It is also observed that about $6.92 \%$ of the articles with the keyword "Coriandrum sativum" are related to diabetes.

According to a previously set strategy, literature searches resulted in 16 articles. Five publications met the inclusion criteria and were included in the final review after thorough analysis (Figure 1). It is possible to see in Table 2 that there is a predominance of trials with rats, more than with mice. The number of animals used in these studies varied from 10 up to 30 and the weight body follows a variation between $120-250 \mathrm{~g}$. Despite not having information of the age of the animals in all the studies, it is possible to verify the range is 7-14 weeks considering two studies $[12,19]$. Furthermore, most of works use coriander collected in natura, which have influence in the method of preparation of the extract, when compared the process with coriander obtained from commercial source.
It is possible to see in Table $\mathbf{3}$ the diabetes induction procedure, protocol experimental, outcomes and conclusion. The three different procedures of diabetes induction: (i) by a single intraperitoneal (i.p) injection of Streptozotocin (STZ), (ii) a single i.p of Alloxan monohydrate and (iii) submitted to a Hypercaloric diet. Overall, the majority of studies in this review (60\%) tested STZ, followed in lower proportions by Alloxan and Hipercaloric diet studies (20\% each). The studies have shown a very similar protocol, with a control group, an induced-diabetic group and a group treated with coriander. Three of the five studies used a standard antidiabetic drug (Glibenclamide, GLZ) as positive control. All the studies observed an antidiabetic activity of coriander.

It is possible to see in Table 4 the influence of the treatment of animals with diabetes with extract of Coriandrum sativum in the plasma profile of some biomarkers. In all the five studies was observed an antidiabetic activity of coriander, decreasing the blood glucose level. Two studies [12,35] reported an increase on plasma insulin level of animals treated with coriander. Sreelatha

Table 3 Diabetes induction procedure, protocol experimental, outcomes and conclusion.

\begin{tabular}{|c|c|c|c|c|}
\hline $\begin{array}{c}\text { Induction of } \\
\text { diabetes }\end{array}$ & Protocol & Outcomes & Conclusion & Reference \\
\hline Alloxan & $\begin{array}{l}\text { Control } \\
\text { Diabetic control }(150 \mathrm{mg} / \mathrm{kg}) \\
\text { Alloxan+ CS Leaf extract }(200 \mathrm{mg} / \mathrm{kg}) \\
\text { Alloxan+ CS Steam extract }(200 \mathrm{mg} / \\
\mathrm{kg}) \\
\text { Alloxan Glibenclamide }\end{array}$ & $\begin{array}{l}\text { The leaf and stem extract of } \\
\text { CS showed a significant reduce } \\
\text { in the blood glucose levels } \\
\text { and blood lipids as the total } \\
\text { cholesterol, TC, VLDL, LDL }\end{array}$ & $\begin{array}{l}\text { The data obtained in this study point } \\
\text { out that CS leaves and stem possess a } \\
\text { significant antidiabetic effect. }\end{array}$ & [22] \\
\hline Hipercaloric diet & $\begin{array}{l}\text { Control (Water) } \\
\text { Diabetic and Normal rats } \\
\text {-Baseline } \\
-6 \text { h post-dose } \\
\text { CS-extract }(20 \mathrm{mg} / \mathrm{kg}) \\
\text { Diabetic and Normal rats } \\
\text {-Baseline } \\
-6 \text { h post-dose } \\
\text { Glibenclamide }(2.5 \mathrm{mg} / \mathrm{kg}) \\
\text { Diabetic and Normal rats } \\
\text {-Baseline } \\
-6 \mathrm{~h} \text { post-dose }\end{array}$ & $\begin{array}{l}\text { CS-extract group reduce the } \\
\text { blood glucose levels from } \\
\text { Diabetic rats (highly significant) } \\
\text { and normal. In addition, } \\
\text { decrease the lipids levels and } \\
\text { insulin resistance in Diabetic } \\
\text { rats. }\end{array}$ & $\begin{array}{l}\text { This study demonstrates that } \\
\text { administration of CS in diabetics rats } \\
\text { normalized glycemia and decreased } \\
\text { the elevated Insulin Resistance, levels } \\
\text { of insulin, total cholesterol, LDL- } \\
\text { cholesterol, and triglycerides and } \\
\text { could decreased hyperglycemia as well } \\
\text { as prevent or reduce Cardiovascular } \\
\text { complications. }\end{array}$ & [19] \\
\hline Streptozotocin & $\begin{array}{l}\text { Control } \\
\text { Streptozotocin }(45 \mathrm{mg} / \mathrm{kg}) \\
\mathrm{STZ}+\mathrm{CS}(10 \mathrm{~g} / 100 \mathrm{~g} \text { feed }) \\
\text { Control + CS (10 g/100 g feed })\end{array}$ & $\begin{array}{l}\text { The CS produced significantly } \\
\text { decrease in blood glucose } \\
\text { levels and significantly } \\
\text { increase in plasma insulin } \\
\text { level and reduction in glycated } \\
\text { hemoglobin, when compared } \\
\text { with diabetic rats. }\end{array}$ & $\begin{array}{l}\text { The results indicate that coriander seeds } \\
\text { possess beneficial action on kidney and } \\
\text { pancreas. }\end{array}$ & \\
\hline Streptozotocin & $\begin{array}{l}\text { Control } \\
\mathrm{STZ}+\mathrm{CS}(100 \mathrm{mg} / \mathrm{kg}) \\
\mathrm{STZ}+\mathrm{CS}(200 \mathrm{mg} / \mathrm{kg}) \\
\mathrm{STZ}+\mathrm{CS}(250 \mathrm{mg} / \mathrm{kg}) \\
\text { Glibenclamide }(600 \mu \mathrm{\mu g} / \mathrm{kg})\end{array}$ & $\begin{array}{l}\text { The CS extract at doses of } 100, \\
200 \text { and } 250 \mathrm{mg} / \mathrm{kg} \text { significantly } \\
\text { decreased serum glucose. In } \\
\text { addition, increased the insulin } \\
\text { releasing activity. }\end{array}$ & $\begin{array}{l}\text { The results have shown that CS } \\
\text { possesses a hypoglycaemic effect on } \\
\text { Streptozotocin-induced hyperglycemic } \\
\text { rats and thus validates to some extent } \\
\text { the folk use of this plant. }\end{array}$ & [35] \\
\hline Streptozotocin & $\begin{array}{l}\text { Control + Agrimony or } \\
\text { Alfalfa or Coriander or Eucalyptus or } \\
\text { Juniper. } \\
\text { STZ }(200 \mathrm{mg} / \mathrm{kg})+\text { Agrimony or Alfalfa } \\
\text { or Coriander or Eucalyptus or Juniper. }\end{array}$ & $\begin{array}{l}\text { Treatment with coriander } \\
\text { consistently lowered mean } \\
\text { values for basal plasma glucose } \\
\text { concentrations in the diabetic } \\
\text { mice. }\end{array}$ & $\begin{array}{l}\text { This study suggests that treatment with } \\
\text { CS does not significantly affect plasma } \\
\text { insulin concentrations. }\end{array}$ & [36] \\
\hline
\end{tabular}


Table 4 Effects of Coriandrum sativum in some blood biomarkers.

\begin{tabular}{|l|c|c|}
\hline Biomarkers & Coriandrum sativum effects & References \\
\hline Glucose & Decrease & {$[12,19,22,35,36]$} \\
\hline Plasma Insulin Level & Increase & {$[12,35]$} \\
\hline Total Cholesterol & Decrease & {$[22]$} \\
\hline HDL- cholesterol & Increase & {$[22]$} \\
\hline LDL- cholesterol & Decrease & {$[22]$} \\
\hline VLDL- cholesterol & Decrease & {$[22]$} \\
\hline Triglycerides & Decrease & {$[22]$} \\
\hline
\end{tabular}

and Inbavalli, [22] have pointed out an improvement on blood lipid profile.

\section{Discussion}

The investigations about diabetes mellitus have relevant due to various clinical disorders associated with this disease, as well as the cost involved with its management [5]. These considerations justify the elevated number of publications in PubMed with the keywords diabetes or diabetes mellitus (Table 1 ). The relevance of the experimental models with natural products that could be used in the management of diabetes reveals the importance of the coriander (Table 1). About $6.92 \%$ of the publications with the keyword "Coriandrum sativum" involve diabetes. Five studies have reached the inclusion criteria to be analyzed. In all these investigations a reduction of the plasma level of glucose was detected in the animals treated with coriander. Due the side effects associated with the use of insulin and oral hypoglycemic agents, there is an increasing demand by patients to use natural products with antidiabetic activity [8]. Coriander have stood out as a promising natural source with relevant effects in treatment of diabetes $[19,22]$, despite the small number of publications in the PubMed database involving the keyword Coriandrum sativum AND diabetes, as shown in Table 1.

Following, the findings of the selected papers are discussed. The procedures to prepare the extract of the coriander are different due the source of this medicinal plant (commercial or in natura) (Table 2). Certainly, it would be preferable, if and when possible, to compare studies homogeneous in terms of species and age of animals. As it was shown in Table 2, two species of animal with different ages and weights were used in the studies. The main findings of the selected papers reveal the importance of the coriander in improving the clinical conditions of the diabetic animals.

The current study has several limitations that must be considered in the interpretation of the findings in this systematic review [36]. It is suggested to take care in generalizing these results due to the analyzed publications have methodological variations concerning to the specie of the animals, the kind of source of Coriandrum sativum, type of the protocols. In addition, although we tried to retrieve the articles following the selected keywords, it may not be sure that it was retrieved all the papers identified for inclusion, including articles that were not published in English and articles published in journals that were not indexed in the PubMed database.

Although it possible to verify limitations in this study, it was verified that considering the publications that were analyzed, all of them have reported a decrease in blood glucose level of the diabetic animals due to the treatment with an extract of Coriandrum sativum. The reason of these results may be due to the higher rate of glycolysis, probably by the high activity of hexokinase and phosphoglucomutase, two of the key enzymes of glycolysis, that are increased in the liver of animals administered with coriander [37]. 


\section{Conclusion}

Putting together the findings described in this study and considering the results in the publications, it is possible to conclude and to suggest that the use of coriander could be suitable to try to decrease plasma glucose level of diabetic animals. However, it is important to consider the limited number of publications available in the PubMed involving searches evaluating the antidiabetic effect of coriander. 


\section{References}

1 Pradeepa R, Mohan V (2002) The changing scenario of the diabetes epidemic: implications for India. Indian J Med Res 116: 121-132.

2 Taskinen MR (2002) Diabetic dyslipidemia. Atheroscler Suppl 3: 47-51.

3 Masharani U, German MS (2011) In: Shoback D, Gardner DG, editors. Greenspan's basic \& clinical endocrinology, New York: McGraw-Hil Medical.

4 Alberti KGMM, Zimmet PZ (1998) Definition, diagnosis and classification of diabetes mellitus and its complications. Part 1: Diagnosis and classification of diabetes mellitus. Provisional report of a WHO Consultation. Diabet Med 15: 539-553.

5 International Diabetes Federation (2016) IDF Diabetes Atlas. 7th edn.

6 Sreelatha S, Inbavalli R ( 2011) Antioxidant, antihyperglycemic, and antihyperlipidemic effects of Coriandrum sativum leaf and stem in alloxan-induced diabetic rats. J Food Sci 77: 119-123.

7 Grover JK, Yadav S, Vats V (2002) Medicinal plants of India with antidiabetic potential. J Ethnopharmacol 81: 81-100.

8 Anila L, Vijayalakshmi NR (2002) Flavonoids from Embilica officinalis and Magnifera indica -effectiveness for dyslipidemia. J Ethnopharmacol 79: 81-87.

9 Khan A, Safdar M (2003) Role of Diet, Nutrients, Spices and Natural Products in Diabetes Mellitus. Pak J Nutr 2: 1-12.

10 Najafabad MA, Jamei R (2014) Free radical scavenging capacity and antioxidant activity of methanolic and ethanolic extracts of plum (Prunus domestica L.) in both fresh and dried samples. Avicenna J Phytomed 4: 343-353.

11 Ramadan MF, Kroh LW, Mörsel JT (2003) Radical scavenging activity of black cumin(Nigella sativa L.), coriander (Coriandrum sativum L.), and niger (Guizotia abyssinica Cass.) crude seed oils and oil fractions. J Agric Food Chem 51: 6961-6969.

12 Deepa B, Anuradha CV (2011) Antioxidant potential of Coriandrum sativum L. seed extract. Indian J Exp Biol 49: 30-38.

13 Kahkonen MP, Hopia Al, Vuorela HJ (1999) Antioxidant activity of plant extracts AJP, containing phenolic compounds. J Agric Food Chem 47: 3954-3962.

14 Dai J, Mumper RJ (2010) Plant phenolics: extraction, analysis and their antioxidant and anticancer properties. Molecules 15: 7313-7352.

15 Moresco HH, Colla G, Cavalcante ID, Queiroz GS, Pizzolatti MG, et al. (2016) Chemical constituents of Eugenia catharinae and their antioxidant activity. Nat Prod Res 13: 1-5.

16 Zugic A, Jeremic I, Isakovic A, Arsic I, Savic S, et al. (2016) Evaluation of Anticancer and Antioxidant Activity of a Commercially Available CO2 Supercritical Extract of Old Man's Beard (Usnea barbata). PLoS One 11: e146-342.

17 Fleischer T, Chang TT, Chiang JH, Chang CM, Hsieh CY, et al. (2016) Adjunctive Chinese Herbal Medicine therapy improves survival of patients with chronic myeloid leukemia: a nationwide populationbased cohort study. Cancer Med.

18 Li CL, Huang HL, Wang WC, Hua H (2015) Efficacy and safety of topical herbal medicine treatment on recurrent aphthous stomatitis: a systemic review. Drug Des Devel Ther 10: 107-115.

19 Aissaoui A, Zizi S, Israili ZH, Lyoussi B (2011) Hypoglycemic and hypolipidemic effects of Coriandrum sativum L. in Meriones shawi rats. J Ethnopharmacol 137: 652-661.

20 Thomas A, Rajesh EK, Kumar DS (2016) The Significance of Tinospora crispa in Treatment of Diabetes Mellitus. Phytother Res.

21 Azimi P, Ghiasvand R, Feizi A, Hosseinzadeh J, Bahreynian M, et al. (2016) Effect of cinnamon, cardamom, saffron and ginger consumption on blood pressure and a marker of endothelial function in patients with type 2 diabetes mellitus: A randomized controlled clinical trial. Blood Press 12: 1-8.

22 Sreelatha S, Inbavalli R (2012) Antioxidant, antihyperglycemic, and antihyperlipidemic effects of Coriandrum sativum leaf and stem in alloxan-induced diabetic rats. J Food Sci 77: T119-123.

23 Brindis F, González-Andrade M, González-Trujano ME, Estrada-Soto S, Villalobos-Molina R (2014) Postprandial glycaemia and inhibition of $\alpha$-glucosidase activity by aqueous extract from Coriandrum sativum. Nat Prod Res 28: 2021-2025.

24 Burdock GA, Carabin IG (2009) Safety assessment of coriander (Coriandrum sativum L.) essential oil as a food ingredient. Food and Chemical Toxicology 47: 22-34.

25 Seidemann J (2005) World spice plants: economic, usage, botany, taxonomy. Berlin Heidelberg: Springer-Verlag.

26 Khani A, Rahdari T (2012) Chemical composition and insecticidal activity of essential Oil from Coriandrum sativum seeds against Tribolium confusum and Callosobruchus maculatus. ISRN Pharmaceutics 2012: 263-517.

27 Ishikawa T, Kondo K, Kitajima J (2003) Water-soluble constituents of coriander. Chemical \& Pharmaceutical Bulletin 51: 32-39.

28 Kubo I, Fujita K, Kubo A, Nihei K, Ogura T (2004) Antibacterial activity of coriander volatile compounds against Salmonella choleraesuis. J Agric Food Chem 52: 3329-3332.

29 PDR-HM (2007) In: Gruenwald, J. (Ed.), Physicians' Desk Reference for Herbal Medicine. 4 ed. Thomson Healthcare Inc., Medical Economics, Montvale, NJ. pp: 228-230.

30 Fujita K (2004) Antioxidant activity of Coriander volatile compounds against salmonella choleraesteis. J Agri Food Chem 4: 3329-3332.

31 Lal AA, Kumar T, Murthy PB, Pillai KS (2004) Hypolipidemic effect of Coriandrum sativum L. in triton-induced hyperlipidemic rats. Indian J Exp Biol 42: 909-912.

32 Usmanghani K, Saeed A, Alam MT (1997) Indusyunic medicine: traditional medicine of herbal, animal, and mineral origin in Pakistan. Faculty of Pharmacy, University of Karachi.

33 Duke JA, Bogenschutz-Godwin MJ, Du celliar J, Duke PAK (2002) Handbook of Medicinal Herbs, 2nd Edition, CRC Boca Raton.

34 PRISMA (2016) Transparent Reporting Of Systematic Reviews and Meta-Analyses.

35 Eidi M, Eidi A, Saeidi A, Molanaei S, Sadeghipour A, et al. (2009) Effect of coriander seed (Coriandrum sativum L.) ethanol extract on insulin release from pancreatic beta cells in streptozotocin-induced diabetic rats. Phytother Res 23: 404-406.

36 Swanston-Flatt SK, Day C, Bailey CJ, Flatt PR (1990) Traditional plant treatments for diabetes. Studies in normal and streptozotocin diabetic mice. Diabetologia 33: 462-464.

37 Chithra VS, Leelamma S (1999) Coriandrum sativum - mechanism of hypoglycemic action. Food Chemistry 67: 229-231. 